\title{
AS MOEDAS DOENTES, OS NÚMEROS PÚBLICOS E A ANTROPOLOGIA DO DINHEIRO*
}

\author{
Federico Neiburg
}

As crises monetárias das últimas décadas do século XX tiveram entre outros efeitos o de colocar em evidência o caráter convencional do dinheiro. Talvez nunca antes (nem com o fim do padrão ouro, no período entre as duas Guerras Mundiais) o espaço público tenha estado agitado como naquela época em função de debates a respeito dos fundamentos do valor da moeda. Em vários países, os dispositivos implementados pelos especialistas para curar ou substituir as moedas nacionais ameaçadas pela "doença da inflação" foram colocados em relação às idéias e às práticas monetárias das populações às quais estavam dirigidos. Ao ter como referência empírica as inflações brasileira e argentina, o meu objetivo é explorar esses singulares processos de desnaturalização pública do valor da moeda para propor uma contribuição à antropologia do dinheiro que tenha como eixo o exame das articulações entre as idéias e as práticas monetárias eruditas e ordinárias.

A relativa ausência de interesse por esses assuntos por parte da literatura deve-se ao predomínio de duas matrizes analíticas que considero constituírem um obstáculo para a compreensão dos sentidos sociais e culturais do dinheiro. Uma é a matriz analítica normativa, que prevalece em boa parte da literatura sociológica, tributária da própria ciência econômica, e que está preocupada em diagnosticar a "natureza" dos "problemas monetários", distinguindo entre moedas "normais" e "doentes". A outra é a matriz que predomina em boa parte da literatura antropológica, que observa a moeda através das lentes da grande divisão entre as moedas "modernas" e as "outras". A primeira matriz não se preocupa com os sentidos ordinários do dinheiro e, quando o faz, é com a intenção de elaborar mecanismos que visem ajustá-los aos sentidos "corretos", aqueles definidos pelos especialistas. A segunda matriz enfatiza a separação entre ambos os universos, deixando toda consideração a respeito do dinheiro moderno nas mãos dos economistas - na verdade, supondo que o dinheiro moderno é aquele descrito pelos 
profissionais da economia, e esquecendo que o deles é também um universo de sentidos e de práticas suscetível de ser analisado como qualquer outro universo nativo.

Na primeira seção deste ensaio, é apresentado um breve panorama de alguns dos efeitos destas e de outras dicotomias sobre a antropologia do dinheiro. Assim, será possível explicitar o ponto de vista que sustenta este texto, situado na fronteira entre a antropologia da ciência (econômica) e a antropologia das culturas monetárias. A hipótese mais geral do meu argumento é que uma melhor compreensão dos sentidos sociais e culturais do dinheiro exige considerar ao mesmo tempo: 1. a presença dos modelos e dos dispositivos monetários criados pelos especialistas nos sentidos e nas práticas ordinárias associadas com o dinheiro; 2. a presença das idéias e das práticas monetárias ordinárias nas formas através das quais os especialistas percebem e agem sobre a moeda; 3. o fato de que os universos de produção de idéias e de dispositivos monetários eruditos, isto é, aqueles que estão referidos às teorias e às políticas monetárias, são suscetíveis de serem analisados com os mesmos instrumentos que utilizamos para estudar qualquer outro universo nativo; e 4. que esse universo de sentidos e de práticas, o que não poderia ser de outro modo, está situado no tempo e exige uma análise histórica.

Ao contrário dos habitantes de outros países que foram também atingidos no fim do século XX por agudas crises monetárias (como Bolívia e Equador, na América Latina; ou Turquia, Israel e os países surgidos do colapso da União Soviética), as populações do Brasil e da Argentina conviviam há várias décadas com aumentos constantes nos índices do custo de vida e com os dispositivos criados pelos especialistas para conceituar e enfrentar a perda do valor das suas moedas nacionais. Esses dispositivos eram apresentados como instrumentos para que as populações pudessem se defender dos efeitos nocivos da inflação, ou como mecanismos destinados a que tirassem partido dela. Na segunda seção do artigo, são descritas as relações entre os universos da economia erudita e ordinária, examinando-se alguns usos sociais dos índices de medição de preços. Ao observarmos certos elementos da sociogênese da categoria custo de vida, que relaciona quantitativamente o valor da moeda com o valor da vida humana, interessa sublinhar o seu caráter de categoria-chave da cosmologia econômica, ao mesmo tempo paradigma de números públicos. ${ }^{1}$ De fato, os índices que medem o custo de vida têm se transformado em objeto de uma enorme confiança social, em boa medida responsável pela transformação em intelectuais públicos dos especialistas que os produzem e manipulam — os "profissionais da economia", não só os economistas acadêmicos, mas também os jornalistas, os funcionários de agências internacionais e de governo, os operadores de mercado e, em ter- 
mos mais gerais, utilizando uma expressão de inspiração weberiana, todos aqueles indivíduos que vivem "de" e "para" a economia.

As seções seguintes do trabalho descrevem outras dimensões da intensa relação que, na história recente, brasileiros e argentinos têm mantido com os números públicos, especialmente quando, a partir da década de 1960, a inflação começou a se transformar em assunto público de primeira grandeza, adquirindo ainda o caráter de sinônimo de crise nacional. ${ }^{2}$ A generalização do uso de indexadores (fundamentalmente no Brasil) e de divisas estrangeiras (especialmente na Argentina) eram sintomas daquilo que os especialistas consideravam como "desajustes" das principais funções do dinheiro: a sua utilização como unidade de conta, como meio de câmbio (e de pagamento) e como reserva de valor. O uso de moedas paralelas, a estruturação de modalidades singulares de consumo e de poupança foram, todos eles, modos através dos quais brasileiros e argentinos lidaram com processos inflacionários prolongados.

Ao contrário do que um espírito alheio a esses processos poderia acreditar, não se trata em absoluto de assuntos abstratos. O convívio com inflações prolongadas, a percepção da perda diária (ou hora a hora) do valor da moeda têm, entre outros efeitos, o de tornar instável a identidade das pessoas, introduzindo agudas incertezas nas perspectivas temporais dos coletivos humanos. No plano familiar, por exemplo, isso envolve práticas e idéias relacionadas com a herança e com a poupança; a diminuição, a ruína (ou ainda a percepção do risco de ruína) das economias familiares. Estes são assuntos que argentinos e brasileiros experimentaram mais de uma vez, tanto nos surtos de "liquidez" em que sobrava dinheiro sem valor, como nos períodos de "seca" em que faltava dinheiro, ou ainda naqueles em que o dinheiro foi confiscado ou ficou retido nos bancos — várias vezes na história recente de ambos os países, como resultado, justamente, da aplicação de políticas antiinflacionárias. Assim, as formas sempre criativas, e certamente diferenciadas, associadas a trajetórias pessoais e familiares singulares, com capitais sociais, culturais e escolares específicos, através das quais as pessoas lidam com a instabilidade monetária e com os dispositivos criados pelos profissionais da economia para combatê-la, colocam-nos diante do assunto central deste artigo: as articulações entre as idéias e as práticas monetárias eruditas e as ordinárias.

A economia nasceu como disciplina acadêmica, concebendo-se a si própria como a única "verdadeira" ciência social, justamente devido à sua capacidade de representar numericamente os fatos sociais, assumindo uma ambição ao mesmo tempo descritiva e normativa a respeito do seu objeto (ver Elias 2006 [1984] e Foucault 1994). Como a medicina, a economia procura 
diagnosticar as doenças, ao mesmo tempo em que prescreve a forma de curá-las. Assim, tratar das relações entre as idéias e as práticas monetárias eruditas e ordinárias permite comentar um assunto que tem alcançado certa importância na antropologia e na sociologia da ciência nos últimos anos: a questão da "performatividade" ou, em outros termos, a questão dos "efeitos" das teorias no mundo social.

Na seção final do ensaio, explicito em que sentido o meu argumento coloca-se por fora, e procura ser mais complexo que as duas alternativas hoje disponíveis. Por um lado, a dos teóricos da performatividade, como Michel Callon ou Bruno Latour, que consideram que a vida econômica tende a ser cada vez mais o resultado da moldagem (ou da formatação) da disciplina econômica (p.e., Callon 1998 e Callon \& Latour 2001). Por outro lado, a dos partidários das "teorias nativas", como Daniel Miller (p.e., 2002), que consideram que, independente das pretensões dos economistas, as pessoas continuam experimentando o mundo social segundo categorias ordinárias. Diante destas posições, propõe-se aqui uma análise dinâmica que rejeita qualquer causalidade simples, além de toda visão romântica sobre a autonomia das práticas e das idéias nativas que permaneceriam alheias aos dispositivos criados pelos especialistas. Trata-se, ao contrário, de examinar empiricamente, e em perspectiva histórica, a dinâmica complexa que conecta os teóricos e as teorias da economia com as culturas econômicas que eles consideram nos seus modelos e que também contribuíram para gerar. ${ }^{3}$

\section{As moedas dos economistas, dos sociólogos e dos antropólogos}

A fronteira que separa um aumento de preços "suportável" e "sadio", que ainda poderia estimular o crescimento econômico, de outro que merece cuidados, e a distinção entre uma "simples" inflação e uma crise hiperinflacionária são assuntos que mobilizam as paixões dos especialistas desde que, em função da inflação alemã dos anos 1920, foram enunciadas as primeiras formulações com pretensões científicas a respeito das diferenças entre, por exemplo, as inflações que se arrastam (creep), que trotam (trot), ou que galopam (galop) (ver, p.e., Feldman 1993:7).

De fato, as "desordens monetárias" européias pós-Primeira Guerra Mundial foram vistas por esses novos profissionais, que eram os economistas $^{4}$, como laboratórios para a imaginação de terapias monetárias. Figuras que se tornariam célebres, como Constantino Bresciani-Turroni, Ludwig Von Misses, Lionel Robbins ou John Maynard Keynes, devem boa parte da sua reputação posterior às suas explicações dos fenômenos inflacionários e 
às suas propostas para estabilizar o valor do dinheiro. Ainda que não seja este o lugar apropriado para examinar de perto tais formulações, interessa assinalar que, fora as muitas diferenças entre eles, esses grandes nomes da disciplina econômica sempre mantiveram certo consenso sobre os efeitos "degenerativos" da atividade econômica ocasionada pela inflação: para além de "certo nível" e de "determinado tempo", a perda do valor da moeda e, mais do que isso, a incerteza sobre o seu valor futuro deveriam ser consideradas, segundo todos eles, como sintomas de uma autêntica doença. ${ }^{5}$

Como se sabe, os economistas associados às correntes "ortodoxas" (ou monetaristas) têm se preocupado em explicar o valor do dinheiro como uma função da oferta de moeda: quanto maior o volume de circulante, menor será o valor de cada unidade. No entanto, as suas formulações têm padecido de certa ambigüidade, na medida em que consideram a moeda ao mesmo tempo como uma mercadoria igual a qualquer outra (sujeita por isso às leis da oferta e da procura) e como a única mercadoria que merece ser objeto de políticas reguladoras do controle da oferta, por meio do crédito e das taxas de juros. As correntes "heterodoxas", por outro lado, têm sublinhado a dimensão fiduciária do dinheiro, a idéia de que este basicamente envolve crédito (no sentido de crença ou confiança) e respeito da autoridade última que garante o seu valor: o Estado soberano (ver especialmente Ingham 2004:50-ss). ${ }^{6}$

Para além dessas diferenças, que suscitaram e ainda suscitam grandes embates teóricos e políticos, economistas ortodoxos e heterodoxos têm concentrado suas preocupações em um mesmo assunto: os mecanismos que fixam o preço da moeda. E têm coincidido também na formulação do que deve ser visto como uma verdadeira utopia monetária, segundo a qual uma moeda autêntica ou sadia é - e deve ser - aquela que concentra em um mesmo objeto a capacidade de funcionar como unidade de conta, como meio de troca (e de pagamento) e como reserva de valor. Essa teoria ("funcionalista") do dinheiro, que tem sido o suposto básico das economias Mainstream - e que se repete em todas as definições dos manuais com que são treinados os aprendizes — como toda utopia que procura a própria realização, é basicamente uma teoria normativa, que pretende agir sobre a moeda atuando sobre os usos que as pessoas fazem dela.

Recentemente, alguns autores chamaram a atenção para o fato de que embora os economistas outorguem uma grande centralidade à moeda na sua dimensão prática, isto é, como objeto de políticas no plano "macroeconômico", eles na verdade pouco têm se preocupado em conceituá-la teoricamente (Ingham 2004; Hart 2004; Maurer 2006; Théret no prelo; Zelizer 2003). De fato, os profissionais da economia, a partir das bases teóricas oferecidas pela utopia monetária que orienta as suas ações e idéias, têm mantido 
basicamente um interesse prático no dinheiro, procurando as formas que permitam a realização do ideal de moeda normal ou sadia - aquela que tem um valor estável, facilitando com isso os "negócios", o "crescimento econômico" ou a "vida boa", dependendo da orientação mais ou menos utilitarista ou humanista das perspectivas em jogo. ${ }^{7}$

Essa relativa ausência de um interesse teórico pelo dinheiro é ainda mais significativa quando se observa a falta de atenção aos fatos monetários que predomina também nas "outras" disciplinas sociais — uma conseqüência da divisão do trabalho que foi paralela à sua autonomização como especialidades universitárias, na virada do século XIX para o século XX. Como se sabe, o cenário no qual aconteceu essa divisão do trabalho foi o Methodenstreit, a "querela sobre o método", em que se enfrentaram a Escola Histórica Alemã, de autores como Gustav Schmöller e Max Weber, e a Escola Austríaca de Economia, vinculada ao nome de Carl Menger, um dos fundadores da chamada corrente neoclássica ou marginalista (ver Schumpeter 1996 [1954]:877-ss). A exportação dessa batalha para além das fronteiras da língua alemã foi em boa medida responsável pela crescente internacionalização do predomínio da escola neoclássica na nascente disciplina econômica, e pelo desinteresse pelos fatos monetários por parte da sociologia. A moeda passou a ser vista a partir de então como algo próprio do domínio econômico, que deveria ser tratado por economistas.

No entanto, esse panorama da construção do monopólio da reflexão sobre o dinheiro pelos economistas, e sua aceitação pelos "outros" cientistas sociais, exige nuances e, especialmente, a consideração de dois nomes que têm sido referência importante nas indagações mais recentes sobre os sentidos da moeda: George Simmel e François Simiand, autores das primeiras e por muito tempo as únicas - obras integrais dedicadas ao assunto por não-economistas, e que são tomados aqui menos nos aspectos substantivos dos seus escritos, e mais como referentes dos modelos predominantes em fragmentos significativos da literatura contemporânea.

Nesse sentido, cabe notar que, apesar de em Simmel (1987 [1909]) haver um forte argumento sobre o caráter propriamente social dos laços objetivados no dinheiro, os quais seriam a expressão de formas de "sociação" fundadas no crédito e na confiança ${ }^{8}$, as leituras da sua obra têm sublinhado as idéias por ele propostas a respeito da moeda como um produto (ou como um sintoma) e, ao mesmo tempo, como um instrumento da objetificação das relações sociais e da individualização da vida humana, próprias da modernidade. ${ }^{9}$

Princípios igualmente genéricos para a construção de uma sociologia do dinheiro podem ser reconhecidos na Escola Sociológica Francesa, em especial em François Simiand que, como se sabe, foi o encarregado da seção 
de economia do Année Sociologique (ver Steiner 2005). A tese, fielmente durkheimiana, segundo a qual Simiand estabelece que o dinheiro é antes de mais nada um "fato social total", expressão da vida coletiva de um grupo (Simiand 1934; Mauss 1974 [1934]), encontrou ecos recentes entre os economistas franceses ligados às escolas "regulacionista" e das "convenções" (ver, em especial, Aglietta \& Orléan 2002). Estes autores, que consideram a moeda como um "operador de totalização" (Orléan 2002), observam as crises monetárias que colocam em questão a estabilidade do valor do dinheiro como expressão de "crises da unidade social" (Orléan, no prelo) e, ao mesmo tempo, como um campo privilegiado de estudos, dado o seu caráter "revelador" da própria "natureza" do dinheiro (Théret, no prelo), da "normalidade monetária", coerente com uma ordem social estável e relativamente homogênea.

Embora uma exposição sumária como esta deva necessariamente deixar de lado méritos e nuances de correntes de pensamento e de autores, interessa sugerir como as duas aproximações (referidas genericamente aqui a Simmel e a Simiand) exprimem os ideais monetários dos especialistas, deixando pouco espaço para a pesquisa positiva sobre os sentidos ordinários do dinheiro, e menos espaço ainda para uma indagação sobre as relações entre os sentidos eruditos e os ordinários. Ambas as aproximações pressupõem realidades humanas homogêneas: o predomínio do individualismo objetificado em um caso, a idéia de totalidade social no outro. O primeiro pouco se interessa pelos usos do dinheiro que escapam ao que é descrito como a sua forma moderna (para uma crítica a Simmel neste sentido, ver Zelizer 1994:6-11); o segundo supõe um paralelo entre desordem monetária e anomia, qualificando como negativo o que na verdade merece ser compreendido (para uma crítica à noção de anomia, ver Elias 2000 [1976]:190-3).

No entanto, é na literatura antropológica que se podem encontrar princípios alternativos de compreensão. Quando os antropólogos começaram a se interrogar sobre os fatos monetários nas sociedades que eram o seu objeto, segundo uma nova divisão do trabalho entre as disciplinas - nas quais a economia mercantil não estruturava todas as dimensões da vida social - eles descobriram características muito diferentes daquelas que eram atribuídas ao dinheiro na modernidade, de acordo com os modelos comentados acima. Nas sociedades que mereciam a atenção dos antropólogos, o dinheiro possuía significados múltiplos que estavam atrelados às relações entre as pessoas, às esferas ou aos circuitos singulares de troca (Dalton 1967; Bohannan 1967).

Ao contrário de um sentido único, significados múltiplos; diferentemente de uma moeda, no singular, moedas plurais; em lugar de coletivos humanos 
homogêneos, mundos sociais diferenciados. Mas isso tudo era atribuído às "outras" sociedades, não às modernas sociedades de mercado. Apesar das questões cruciais que suscita, durante longo tempo tal modelo não alcançou o mundo em que vivem os antropólogos. Assim, seguiu-se ao pé da letra a formulação de Karl Polanyi (1957) a respeito da oposição entre moedas para "usos específicos", encontradas nas formas sociais "tradicionais", e moedas para "usos múltiplos", as moedas "modernas". Qualquer indagação sobre o dinheiro moderno ficou restrita às mãos dos economistas e dos sociólogos, aceitando-se assim seu monopólio sobre os fatos monetários. No fim das contas, as "nossas" moedas não mereciam maiores atenções, elas seriam regidas pela utopia dos especialistas relativa à estabilidade do seu valor, e ficariam sujeitas, é claro, às terapias orientadas para corrigirem desajustes e curarem doenças.

Alguns dos trabalhos mais instigantes e influentes realizados por antropólogos nos últimos anos delatam os efeitos negativos da permanência dessa dicotomia. Maurice Bloch e Jonathan Parry (1989), por exemplo, demonstraram de forma muito sutil como a introdução do dinheiro moderno em sociedades tradicionais não teve o efeito de dissolver os laços sociais, produzindo a divisão radical entre pessoas e coisas que seria própria do capitalismo. ${ }^{10}$ Embora Bloch e Parry tivessem sugerido que o papel do dinheiro como unidade de medida abstrata e puramente quantificadora é uma teoria nativa ocidental (ver a respeito Maurer 2006), eles não se dedicaram em momento algum a observar como de fato essa teoria nativa opera na prática, no mundo que ela supostamente descreve.

O problema dos antropólogos com o dinheiro nos seus próprios universos sociais aparece mais claramente ainda em trabalhos como os de David Akin e Joel Robbins (1999), que propuseram uma sugestiva sofisticação das noções de "esfera de troca" e de moedas de "usos múltiplos". Acontece, no entanto, que o modelo elaborado por estes autores para compreender a lógica social e cultural das moedas locais na Melanésia baseia-se em supostos não explicitados nem problematizados a respeito do funcionamento das moedas "ocidentais", ou das "Western notions about Money" (1999:3). Akin e Robbins não se interrogam sobre os conteúdos práticos dessas "Western notions", assimilando-as aos sentidos eruditos, próprios dos especialistas, e implicitamente deixando para eles a reflexão sobre o dinheiro moderno.

Ao identificarem a "natureza" do dinheiro no "Ocidente" com os sentidos que ele tem para a ciência econômica, estes e tantos outros antropólogos não enxergaram a possibilidade de interrogar as relações que entrelaçam as práticas eruditas e as ordinárias, ou a lógica prática que sustenta a elaboração de teorias e de dispositivos monetários por parte dos especialistas. É como 
se no plano da economia e do dinheiro a lente da grande divisão entre "nós e os outros" tivesse tido entre os antropólogos uma força maior do que em outros planos da vida social.

Acontece, porém, que aquilo que essa lente enxerga - o "nosso" dinheiro, supostamente homogêneo e que remeteria a quantidades puras, distinto dos "outros" dinheiros, estes sim, diferenciados e relativos às relações entre os sujeitos - contradiz boa parte da própria experiência dos antropólogos com o dinheiro. Ora, o nosso dinheiro sempre é qualificado. Todos nós operamos com sentidos do dinheiro bom e do ruim; do fácil e do difícil; do forte e do fraco; do virtual e do real. Também, como querem os especialistas, operamos com noções de dinheiro robusto (ou sadio) e doente; na conta do banco ou em espécie; aplicado ou não aplicado; dinheiro devido ou no bolso; sujo ou limpo. Ao olharmos à nossa volta, descobrimos sem dificuldade que o dinheiro não existe de forma puramente homogênea; que a sua realidade é múltipla; que as moedas são plurais; que o dinheiro é singularizado, marcado para fins específicos. Um olhar minimamente atento permite-nos observar a nós mesmos e aos nossos próximos, outorgando sentidos diferentes ao dinheiro trocado dentro de casa (com nossos filhos, esposos ou amantes), e também ao que é intercambiado em outros muitos contextos, menos familiares, com desconhecidos, em situações mais ou menos fugazes.

A percepção da pluralidade dos fatos monetários e da qualidade diferente das moedas é especialmente aguda para os habitantes de países com dinheiro fraco ou, justamente, com moedas doentes. Eles aprendem a lidar com hierarquias monetárias, a tirar proveito das diferenças entre moedas nacionais e moedas paralelas, entre o dinheiro vivo e o dinheiro que agoniza. O tempo passa a ser um elemento crucial de qualificação quando, por exemplo, é preciso se desfazer velozmente do dinheiro no momento em que ele perde o seu valor, antes de já não servir para comprar quase nada.

Ao olhar rapidamente para fatos como esses, resulta ainda mais impressionante que tenhamos tido que esperar até o final dos anos 90 para que autores como Viviana Zelizer (1994) chamassem a atenção para a dimensão qualitativa do dinheiro "entre nós". Acredito que essa desatenção, que essa posição confortável de boa parte dos antropólogos na grande divisão entre "nós" e "os outros" no plano monetário (quando ela já era objeto de um questionamento acirrado em outras áreas da disciplina), tenha a ver também com nossas próprias ambivalências em relação ao dinheiro; ao fato de que ele evoca imagens ambíguas de poder e potência, e também aspectos extremamente sombrios da vida coletiva, associados ao interesse e ao lucro. Evoca também questões acentuadamente íntimas, como a gestão das nossas economias, assuntos árduos de serem pesquisados, que ocasionam incômodo 
e dificilmente são abertos para os melhores amigos, mas que estruturam as vidas individuais e coletivas. ${ }^{11}$

É como se, afinal, apesar de todas as evidências que pudessem estimular a nossa reflexividade a respeito do dinheiro, nós nos curvássemos às representações eruditas sobre as moedas modernas. Segundo elas, tudo o que fosse capaz de ser qualificado em relação ao dinheiro não seria mais do que epifenômeno (ideologia, superestrutura), alguma coisa externa aos fatos propriamente monetários, que seriam antes de mais nada numéricos e totalizantes - a noção de "externalidade", cunhada pela economia neoclássica, sublinha justamente isto: o caráter artificial das qualidades e das singularidades em face dos fatos econômicos. Voltamos assim ao foco deste texto dedicado ao exame das articulações entre as idéias e as práticas monetárias dos especialistas e as formas de experimentar e de dar sentido ao dinheiro na vida ordinária. ${ }^{12}$

\section{Números públicos e culturas monetárias}

Qualquer leitor de jornal, ou freqüentador do noticiário televisivo, está acostumado a dormir e a acordar com indicadores de preços, convive diariamente com o vocabulário que descreve situações e tendências que apelam para uma sucessão de siglas e expressões (como IPC, IGP, "prévia do mês", "quadrisemana", entre tantos outros), seguidas sempre de percentagens e previsões. Ele, ou ela, perceberá com naturalidade o fato de que variações de décimos nessas percentagens possam ser objeto de debates apaixonados, nos quais personagens públicas, revestidas de uma singular autoridade, discorrem sobre o bem-estar de uma população ou sobre o futuro de uma nação.

Essa curiosa meteorologia que está entre nós aparentando sempre ter estado aqui, como um fato da natureza, possui, no entanto, uma história singular. E igualmente singular é a história da transformação dos índices de custo de vida (essas cifras que correlacionam o valor do dinheiro com o da vida humana) em categorias-chave da cosmologia econômica moderna, objeto de crença e de confiança pública.

A idéia de que a vida tem um custo, e que ele pode ser quantificado, isto é, traduzido em uma quantidade de moeda, em um preço, foi formulada talvez pela primeira vez na Inglaterra, no início do século XVIII. ${ }^{13}$ Algumas décadas mais tarde os cálculos de nível de preços, associados à definição de uma cesta básica de bens, ganharam sofisticação nas mãos dos legisladores de Massachussets, interessados em definir uma retribuição "justa" para os soldados envolvidos na Guerra de Independência norte-americana. Pouco 
depois, já no contexto da Guerra Civil, a própria noção de seguro de vida começou a ser formulada, envolvendo toda uma série de operações destinadas à mensuração monetária do valor da vida humana. ${ }^{14}$

No entanto, só se falaria de números índice (index numbers) algumas décadas depois quando, no contexto da revolução neoclássica, a representação numérica dos fatos sociais se transformaria em uma ferramenta básica para o estabelecimento da economia como uma ciência autônoma do comportamento. A paternidade dos index numbers dilui-se entre vários dos primeiros economistas acadêmicos (Laspeyres, Jevons, Edgeworth, Marshall), mas reconhece um dos seus mais célebres formuladores no matemático e economista norte-americano Irving Fisher. Foi na época de Fisher, por volta de 1920, que pela primeira vez foi elaborado, nos Estados Unidos, um índice nacional de custo de vida. ${ }^{15}$

Fisher não se notabilizou apenas pelos desenvolvimentos teóricos e técnicos relativos à medição dos preços. Ele também contribuiu para transformar os próprios index numbers em mercadoria, dando assim passos decisivos para a sua conversão em números públicos. Criou, por exemplo, uma das primeiras "empresas de consultoria", que distribuía entre seus clientes folhas impressas com dados sobre a variação de alguns dos principais preços da economia, introduzindo assim no espaço público econômico norte-americano um novo tipo de informação que não demoraria a mudar a agenda dos jornais de comércio. Pouco antes da crise de 1929, a agência de Fisher colocou pela primeira vez no mercado "títulos indexados" à variação dos índices de preços. ${ }^{16}$ Iniciava-se, dessa maneira, uma mecânica que teria um longo percurso: o mesmo instrumento (o index number), que servia como termômetro para medir o valor do dinheiro, servia também para proteger as pessoas das perdas ocasionadas pela doença da moeda, estimulando ao mesmo tempo o aumento dos preços. Essa circularidade entre teorias e práticas econômicas que está na base da popularização dos indicadores e da sua transformação em números públicos é justamente o tipo de fenômeno sobre o qual me interessa chamar a atenção neste artigo.

$\mathrm{Na}$ segunda metade do século XX, brasileiros e argentinos conviveram intensamente com a instabilidade do valor do dinheiro e com outros fenômenos decorrentes das crises monetárias, como a repetida substituição das moedas nacionais, a proliferação de moedas paralelas, ou o uso intensivo nas transações correntes de divisas estrangeiras ou de moedas locais (emitidas por entidades subnacionais, como as províncias, ou até por grupamentos de pessoas, clubes e associações) ${ }^{17}$ Conviveram também intensamente com mecanismos de "indexação", como os inventados por Fisher.

A transformação dos índices de custo de vida em verdadeiros dispositivos culturais, que circulam para além do restrito âmbito dos especialistas, 
envolve mudanças nas disposições temporais dos agentes sociais, que passam a enxergar através desses números o mundo social - e principalmente as suas relações com objetos e bens cujo valor é mensurado monetariamente, isto é, transformado em preço. As poucas descrições sobre os processos inflacionários (realizadas mais por literatos do que por cientistas sociais) acentuam justamente essa dimensão temporal da experiência inflacionária. ${ }^{18}$ No caso que até agora mereceu maior atenção da literatura, o da Alemanha dos anos 20 (por exemplo, Richard 1983; Feldman 1993; Widdig 2001), acentuam-se dois elementos ausentes nas inflações brasileira e argentina: os efeitos da guerra, e o contraste entre a crise inflacionária e a certeza anterior a respeito da estabilidade do valor da moeda. Após a derrota na Primeira Guerra Mundial - coincidem em apontar os comentadores — os alemães descobririam aquilo que até então era tido como inabalável: a perda do valor do marco alemão.

Ao contrário, brasileiros e argentinos foram longamente educados na instabilidade monetária, interiorizando a idéia de que o valor das suas moedas depende de situações transitórias, é produto de convenções que resultam de condições políticas singulares. A repetida substituição de uma moeda nacional por outra foi, nesse sentido, particularmente pedagógica: entre a década de 1960 e o presente, houve na Argentina cinco moedas nacionais diferentes (Pesos Moeda Nacional, Pesos Lei, Austrais, Pesos Convertíveis, Pesos), e no Brasil, oito (Cruzeiro, Cruzeiro Novo, Cruzeiro, Cruzado, Cruzado Novo, Cruzeiro, Cruzeiro Real, Real).

Na verdade, desde o fim da Segunda Guerra Mundial, e especialmente a partir dos anos 50, a pergunta sobre a natureza e as origens da inflação ganhou um lugar central entre os economistas latino-americanos, ou entre os estrangeiros interessados na região. Não é o caso de me estender aqui sobre os debates da época (entre "estruturalistas" e "monetaristas", por exemplo). O fato é que a densidade desses debates contribuiu para a conformação de um campo de profissionais da economia relativamente autônomo em diversos países do subcontinente, com instituições próprias de formação e difusão de teorias e políticas. No entanto, apesar de toda a atenção dada por esses profissionais ao desequilíbrio monetário, o certo é que, como constatou duas décadas mais tarde Albert Hirschman (1984 [1981]:247), a inflação na América Latina acabou se tornando "onipresente, prolongando-se por um período extenso, aparecendo para as pessoas como alguma coisa familiar e quase 'normal"19.

Justamente, em um longo período de tempo que abrangeu várias gerações, ao debaterem sobre a natureza da inflação e ao criarem mecanismos para lidar com ela, os especialistas desenvolveram uma verdadeira pedago- 
gia da instabilidade monetária; ensinaram os sentidos dos dispositivos que permitiram às populações (do seu ponto de vista, os "agentes econômicos") aprenderem a conviver com a perda do valor da moeda, a se defenderem de seus efeitos nocivos e, também, a aproveitarem as oportunidades abertas por ela. ${ }^{20}$

Uma nota de "etnografia autobiográfica" ilustra esse ponto. ${ }^{21}$ Quando em agosto de 1988 saí de Buenos Aires para começar o meu doutorado em antropologia social no Rio de Janeiro, havia pouco tinham começado a circular na Argentina as notas de Austral, a nova moeda que substituía o Peso (este tinha sido colocado em circulação pouco mais de dez anos antes). Quando desembarquei no Brasil e troquei alguns dólares, recebi uma mistura de novos Cruzados e de antigos Cruzeiros. Alguns meses depois, os Cruzados novos seriam substituídos por novíssimos Cruzeiros. Era inevitável sentir no Brasil certo ar familiar em relação às questões monetárias. No Rio de Janeiro, como em Buenos Aires, as pessoas investiam uma enorme parcela de tempo e de energia ouvindo falar e falando em dinheiro, lidando com assuntos monetários, trocando umas moedas por outras, e trocando compulsivamente dinheiro por outros objetos: comprando. As pessoas pensavam e manipulavam intensamente números.

A paisagem das filas nos supermercados e o barulho das máquinas de marcação de preços (antes da existência dos sistemas digitais hoje correntes) reforçavam a sensação de que - como diziam os mais idosos, que lembravam tempos menos preocupados obsessivamente com o valor do dinheiro "agora nada tem preço". A paradoxal intensificação do consumo, própria dos processos inflacionários que, por sua vez, estimula o desabastecimento que alimenta o aumento dos preços, tinha vários correlatos, inclusive na disposição espacial dos lares. Nas salas dos apartamentos de algumas famílias das classes médias, por exemplo, generalizava-se a utilização dos freezers e das geladeiras suplementares para facilitar a estocagem. ${ }^{22}$

Mas, aos meus olhos, educados na inflação argentina, os brasileiros pareciam conviver de uma forma mais ordenada em relação à vertiginosa perda do valor do dinheiro. A palavra-chave dessa ordem, que eu escutei pela primeira vez no Rio de Janeiro, era "correção monetária" — como foi muito acertadamente batizado no Brasil o dispositivo da indexação, inventado por Fisher, uma figura certamente desconhecida por mim e, é claro, por meus interlocutores na época.

A correção monetária fazia com que os salários dos meus professores, e a minha bolsa inclusive, duplicassem o seu valor a cada 90 dias. Da mesma forma, eram reajustados os aluguéis: como muitos outros contratos, a cada três meses eles dobravam o seu valor nominal. Assim, se tinha a sorte de 
receber o reajuste da minha bolsa no mês anterior ao reajuste do aluguel, ficava na minha mão um montante de dinheiro "quente", que podia ser trocado (e devia ser trocado rapidamente) por outros bens. Ou, senão, eu devia correr até o banco para "aplicar" o dinheiro. Uma das coisas que mais me impressionavam era a freqüência com que meus amigos brasileiros iam ou telefonavam para os bancos. Estudantes como eu, que viviam basicamente de uma bolsa de estudos - não estou falando de grandes investimentos lidavam com contas bancárias, cartões e talões de cheques, com enorme habilidade e parcimônia, movimentando o dinheiro que seria utilizado para chegar até o final do mês entre aplicações diversas, num jogo que eles pareciam dominar à perfeição. Acontece que o dinheiro no banco era também "corrigido", indexado, convertido em uma outra moeda, transformado em um índice. Este era um assunto em relação ao qual, nesse período de intensa desvalorização da moeda, os brasileiros podiam utilizar um conhecimento acumulado durante três décadas.

De fato, trata-se de uma história que nos situa na véspera do golpe de Estado de 1964, quando a demanda por "mais e melhores estatísticas" começou a ser insistentemente veiculada na imprensa por alguns dos que pediam o fim do governo de João Goulart devido, justamente, à sua suposta incapacidade para controlar os preços. Resulta fantástico observar com os nossos olhos do presente, educados em uma percepção quantitativa da inflação, o debate daqueles anos. No Brasil, não havia então índices nacionais de preços. O que merecia mais crédito, por exemplo, segundo algumas dessas usinas golpistas, era o índice de preços do estado da Guanabara, que tinha uma abrangência somente estadual. Isto acentuava o paradoxo: aqueles que discutiam o problema e denunciavam o descontrole do "tigre da inflação", ou os efeitos insuportáveis do "flagelo do aumento dos preços", utilizavam para fundamentar essa denúncia não números, mas um repertório de fórmulas qualitativas, o qual revelava sua suposta incapacidade para conceituar o fenômeno. Para tratar um mal "vagamente" percebido através dessas categorias que prescindiam de quantidades (finalmente, dizia-se, "todo cidadão brasileiro podia sentir a doença no bolso"), seriam necessários instrumentos precisos de diagnóstico, cuja fabricação era vista ao mesmo tempo como o princípio da cura. ${ }^{23}$

A "correção monetária" foi inventada nessa época, imediatamente após o golpe. O Programa de Ação Econômica do governo militar criou uma série de moedas virtuais que serviam para a cotação e para o reajuste de todos os contratos da economia, inclusive os salários. À primeira dessas moedas, a ORTN (Obrigações Reajustáveis do Tesouro Nacional), seguiu-se uma legião de siglas semelhantes, como a URP, que regulava o aluguel e a minha bolsa quando cheguei ao Brasil. 
No pós-Segunda Guerra, e muito mais intensamente ainda a partir da década de 60, o Brasil experimentou uma verdadeira proliferação de indicadores. Esse processo de indexação da vida social e de convívio intenso com os números públicos teve como base, em larga medida, a própria expansão do campo dos profissionais da economia. Formados nas então numerosas faculdades de economia (também em algumas de sociologia com viés estatístico e, depois, nas de jornalismo), e recrutados por um número cada vez maior de instituições patrocinadas pelos governos (federal, estaduais e municipais), por sindicatos de patrões e de trabalhadores, eles concorriam no mercado de idéias e de políticas, elaborando e vendendo index numbers. Estes eram logo consumidos na esfera pública econômica, já bastante povoada pelos "laboratórios" que os elaboravam, por boletins de empresas e de associações, por revistas de grande circulação, por jornais e seções informativas especializadas, o que ampliava, por sua vez, o mercado de trabalho dos profissionais. ${ }^{24}$

Um dos eventos mais significativos desse processo de "indexação do debate público" brasileiro ocorreu após uma denúncia sobre a manipulação, por parte do governo, dos indicadores que serviam para a correção dos salários referentes ao ano de 1973. A denúncia tinha sido encaminhada pelo Departamento Intersindical de Estatística e Estudos Sócio-Econômicos DIEESE que, pouco depois da sua criação, na década de 1950, havia começado a elaborar indicadores de custo de vida. Mas ela ganhou legitimidade pública só em meados de 1977, após a divulgação de um documento sigiloso de uma missão do Banco Mundial que encampava os números do DIEESE e alertava para a tergiversação dos dados produzidos pela Fundação Getúlio Vargas que, naquela época, era o laboratório de produção de indicadores oficiais para o sistema da "correção monetária".

A partir daí, seguiram-se meses de debate público, nos quais os profissionais da economia tiveram uma participação estelar: eram chamados a explicar os mecanismos de elaboração das fórmulas e a discorrer sobre o valor científico da sua atividade tanto na imprensa e no Congresso Nacional (foi criada a "Comissão Parlamentar de Inquérito dos Índices"), como também nas ruas. Alguns economistas e sociólogos compareciam a manifestações e a comícios para os quais eram convidados a discursar. A representação numérica dos fatos sociais e o uso de percentagens estavam tão estabelecidos como a forma legítima de olhar para o mundo social que os coordenadores do "Movimento do Custo de Vida", criado naquela época, regozijavam-se publicamente por terem "superado em 15\% a meta" de 1 milhão de assinaturas para o manifesto de denúncia sobre a "falsidade dos indicadores"25.

Três décadas depois desses fatos, foi inventado o último dos tais números públicos. Ele assumia o seu duplo papel de coeficiente de reajuste diário dos 
preços e de unidade de conta nas transações correntes: era a URV (Unidade Real de Valor), lançada em 1993 com a finalidade de se transformar em uma nova moeda, o Real, até hoje a moeda nacional do Brasil. Alguns dos idealizadores do "Plano Real" eram economistas que tinham obtido certa reputação como autores de uma teoria a respeito das causas da inflação - a chamada teoria da "inflação inercial" — que considerava justamente o papel desses dispositivos na longa instabilidade monetária do país. ${ }^{26} \mathrm{~A}$ única saída para conseguir terminar com a doença da moeda, segundo esses especialistas, era transformar um desses indexadores em moeda corrente. E foi assim que o convívio com a nova moeda foi ensinado à população, que durante alguns meses aprendeu a calcular os preços dos objetos e dos contratos por meio de uma unidade de conta móbil, a URV (cujo valor variava diariamente), e em Reais. Esta última era inicialmente uma moeda apenas virtual, até que a URV gradativamente foi se extinguindo, segundo uma tabela diária de variação com a qual era confrontado todo cidadão que manipulava dinheiro nos pagamentos correntes e também nos contratos, a começar pelos salários e pelos aluguéis, por exemplo.

Como os brasileiros, os argentinos também aprenderam a conviver com os indexadores, mas em uma intensidade e em uma escala sensivelmente menor. Pelo menos dois elementos gravitaram decisivamente em função dessa diferença. ${ }^{27} \mathrm{Um}$ desses elementos é a menor escala relativa do campo dos profissionais da economia na Argentina, e também a intensidade menor da concorrência entre os laboratórios produtores de números, da qual um dos efeitos foi, justamente, a popularização dos indicadores. O outro elemento é a generalização, entre os argentinos, do uso do dólar norte-americano como moeda paralela, em um longo processo que se iniciou nos anos 60. De fato, para os argentinos, o dólar foi aos poucos se convertendo em um equivalente daquilo que, para os brasileiros, eram os coeficientes de indexação. Já no início da década de 60, o preço com que se contrastava o valor da moeda nacional na Argentina era o do dólar. A taxa de câmbio transformou-se muito cedo em um assunto de interesse para amplas camadas da população. Folhas com a cotação das divisas estrangeiras eram produzidas e distribuídas às centenas pelas casas de câmbio da city portenha. ${ }^{28}$

Naquela época, generalizou-se entre as camadas médias argentinas em ascensão a prática da poupança em dólar (para a maioria, no "colchão", e para alguns privilegiados, em contas no exterior). O debate público sobre a geração de um mercado de capitais nacionais, inclusive a tentativa de criar uma "cultura da poupança" em moeda nacional por parte dos bancos, denota a preocupação com o uso cada vez mais generalizado do dólar como meio de entesouramento. A criação de mercados de bens específicos em 
dólar (notadamente de bens imóveis) foi uma decorrência natural desse processo. Ainda hoje os argentinos pensam sempre no valor das moradias em dólar; as propriedades são avaliadas por meio da divisa estrangeira, igual ao preço publicado nos avisos classificados, e as transações são feitas em dólar usando sempre "dinheiro vivo", o que envolve uma logística - e uma ritualística - especial, relativa aos meios de transporte das notas e aos lugares adequados para as transações - o que resulta extremamente exótico para os observadores estrangeiros.

Os elaboradores de políticas de estabilização monetária na Argentina também reconheceram cedo essa "dolarização das mentes nacionais" ${ }^{29}$. De fato, o primeiro ensaio de dolarização geral aconteceu no país em dezembro de 1978, com a instituição da chamada tablita (tabelinha), que permitia prever a desvalorização diária do peso em relação ao dólar. Esperava-se que a regulação de um preço (o do dólar) servisse para orientar todos os outros preços da economia. Realmente, durante vários meses, os argentinos pensaram as suas relações (mediadas pelo dinheiro) com os objetos e com as pessoas calculando os coeficientes estabelecidos pela tablita. Mas a dolarização aconteceria na verdade pouco mais de dez anos depois, após a crise hiperinflacionária que marcou o fim do Austral e a instituição do regime da Conversibilidade - tecnicamente um sistema de currency board que estabelecia por lei a paridade de 1 peso $=1$ dólar. Esse sistema fez com que os cidadãos pudessem utilizar indistintamente em qualquer transação, mesmo nas de mais baixo valor, como comprar cigarros ou pagar um táxi, notas de Pesos Conversíveis ou de dólares, acostumando-se a manusear cotidianamente, e ao mesmo tempo, ambas as moedas. Naquela época, a institucionalização da dolarização na Argentina abriu um debate em várias outras partes do mundo. Nele foram discutidas as relações entre estabilidade monetária e soberania. Alguns dos autores do Plano Real, por exemplo, posicionaram-se claramente contra essa alternativa para o Brasil, argumentando que os brasileiros confiavam ainda na sua moeda, e lembrando que os mecanismos da indexação tinham tido justamente a vantagem de "manter as cabeças brasileiras" voltadas para um horizonte de equivalências basicamente nacional. ${ }^{30}$

\section{Conclusões}

Em um estudo iluminador sobre os debates a respeito da natureza e do futuro da moeda que se seguiram ao fim da Guerra Civil nos Estados Unidos, Bruce Carruthers e Sarah Babb (1996) demonstraram a utilidade da análise 
das situações de crise para que se compreendessem os sentidos públicos do dinheiro. Ao seguir as idéias de Mary Douglas (1986) a respeito da relação entre a naturalização e a estabilidade das instituições sociais, Carruthers e Babb colocaram em evidência como em contextos inflacionários a natureza da moeda deixa de ser taken for granted; a sua reprodução como laço social fundado na confiança e na continuidade do seu valor não é mais vista como não-problemática; o preço da moeda (ou a quantidade de dinheiro que deve ser trocada por outros bens ou serviços) transforma-se em uma questão que preocupa os espíritos não só dos especialistas que discutem alternativas para a estabilização, mas também das pessoas que lidam com dinheiro nas suas transações cotidianas.

A particular desnaturalização pública da moeda nesses momentos pode ser observada nos esforços realizados por aqueles que estão afastados das crises para poderem compreender o que ali se passa. Assim, por exemplo, nos primeiros meses do ano 2002, a rede britânica BBC publicou no seu site da Internet um "Dictionary of Argentine Crisis" com a finalidade de ajudar os leitores a entenderem os sentidos das questões que envolviam termos como "conversibilidade", "bônus", "pesificação", "dolarização" ou "corralito". Enquanto as pessoas não familiarizadas com os acontecimentos que naquele momento comoviam o país podiam informar-se através desse e de outros meios sobre o que ali estava ocorrendo, os argentinos "debatiam a crise" nas ruas, em passeatas e assembléias, ao mesmo tempo em que os intelectuais de maior renome no país apareciam reiteradamente na mídia discutindo os destinos da nação - alguns perguntavam-se, inclusive, se a Argentina "continuaria a existir depois da crise".

Nessa época, no vizinho Brasil, o fantasma da "argentinização" aparecia nos debates públicos sobre o futuro da economia e da política. Não era a primeira vez que se invocavam os riscos da contigüidade, aparentemente sempre tão afins com a dimensão internacional do desequilibro financeiro cerca de vinte anos atrás, difundiram-se algumas expressões que descreviam a perda súbita do valor das moedas nacionais em termos de contágio (como a teoria do "efeito Orloff", segundo a qual dizia-se no Brasil, "a Argentina de hoje é o Brasil de amanhã"). ${ }^{31}$

Como vimos, o desequilíbrio monetário não era novidade para argentinos e brasileiros. Há muito tempo, as populações de ambos os países conviviam com fenômenos semelhantes, aprendendo a identificar a perda do valor das suas moedas com momentos fortes no debate público a respeito da crise e do destino da nação. Qualquer um que tenha vivido no Brasil ou na Argentina nas últimas décadas do século passado e nos primeiros anos deste século não terá dificuldade em lembrar os repetidos anúncios, em ca- 
deia nacional de rádio e televisão, de congelamentos de preços, poupanças forçadas e mudanças de denominação das moedas correntes, seguidos de feriados bancários em que os assalariados, os devedores, os locatários, enfim, a maior parte dos cidadãos era exposta aos novos dispositivos concebidos para salvar a coletividade da peste da instabilidade monetária: novas moedas, deságios, tabelas de conversão, indexadores. A intensidade das formas rituais que envolvia os anúncios e a implantação desses dispositivos sublinhavam o caráter extraordinário do tempo das moedas doentes. ${ }^{32}$

Não é este o lugar para descrever em detalhes a construção da identificação entre crise da moeda e crise nacional; nem a dinâmica ritual que envolve a utilização de metáforas naturais que falam de saúde e doença, e que têm nos profissionais da economia, transformados em intelectuais públicos, um dos seus principais oficiantes. ${ }^{33}$ Interessa, sim, chamar a atenção para os enormes efeitos pedagógicos desses longos períodos de instabilidade monetária, de "dinheiro selvagem", na feliz metáfora de Cris Gregory (1997).

Isto reforça uma das idéias gerais deste texto, que indica a utilidade da reconstrução do longo e lento processo de cultivação econômica para a compreensão dos comportamentos individuais e coletivos nos momentos de crise ou hiperinflação. Certamente, esses momentos são privilegiados para o exercício da pedagogia da economia, mas só na condição de que neles possam também ser mobilizadas disposições já incorporadas em períodos de relativa estabilidade e bem-estar.

Volta-se, assim, à questão das relações entre as teorias e os dispositivos monetários construídos pelos especialistas e aqueles presentes na vida ordinária. Dessa forma, é possível concluir este artigo com um comentário a respeito da questão da performatividade, de como ela passou a ser lida a partir da publicação, em 1998, do livro de Michel Callon, The laws of the market - uma abordagem que, aliás, influenciou não só os estudos sociais da economia, mas também a chamada Action Network Theory, que tem como principal foco os Science and Technology Studies.

Ao remeter-se vagamente à teoria de John Austin (1972) sobre os atos de fala e dialogando implicitamente com as idéias de Pierre Bourdieu (1981) sobre os efeitos da teoria na vida social, Callon formula, na introdução desse volume, uma hipótese segundo a qual a teoria econômica teria o efeito de moldar as práticas econômicas - o fato de que, segundo suas palavras, a vida econômica (a economy) está embebida não na sociedade (como diria Karl Polanyi), mas na economics, na teoria econômica (Callon 1998:30). ${ }^{34}$

A proposta de Callon, independente de ter o mérito de chamar a atenção para um assunto crucial, mereceu até agora duas críticas principais. A primeira delas refere-se menos ao conteúdo da hipótese e mais às evi- 
dências apresentadas. Segundo MacKenzie e Millo (2003), por exemplo, o processo de formatação, a performatividade, ainda estaria à espera de demonstrações empíricas plenamente convincentes.

A outra crítica a Callon, explicitada em especial por Daniel Miller (2002), questiona um ponto central da hipótese: a própria idéia de que a teoria econômica produza um efeito de "purificação" (ou desentanglement) da vida econômica, particularmente das transações, formatando-as segundo o ideal do mercado auto-regulado. No que parece ser uma nova edição do antigo debate entre partidários de interpretações "formais" ou "substantivas" da economia (debate que agitou, como se sabe, a chamada antropologia econômica nos anos 1950 e 1960), pessoas como Miller, que estaria do lado substantivista, digamos assim, têm procurado mostrar que uma tal purificação nunca se produz realmente; ou que, em todo caso, os dispositivos de formatação econômica fabricados pela teoria, passam, eles mesmos, a ser capturados e misturados nas transações, que seriam sempre algo a mais e algo diferente do que transações puramente econômicas. Neste sentido, é preciso concordar com Miller: Callon não teria feito mais do que reproduzir a visão (otimista) que os próprios economistas têm sobre os efeitos das suas teorias sobre a vida social. ${ }^{35}$

Creio, no entanto, que apesar dos seus vários aspectos produtivos, esse debate não atingiu ainda alguns pontos cruciais das relações entre as teorias econômicas eruditas e as práticas econômicas ordinárias. Para concluir, gostaria de chamar a atenção sobre três desses pontos, em relação aos quais a minha proposta de antropologia do dinheiro através da história cultural da inflação busca oferecer uma visão diferente.

O primeiro ponto exige substituir uma noção unificada da teoria econômica - compartilhada por Callon e por seus críticos - que atribui homogeneidade e agency à teoria (tratada sempre no singular), por uma visão nuançada das relações de interdependência e de concorrência entre as teorias (no plural) e, mais importante, entre os seus produtores e divulgadores. A discussão sobre performatividade parece esquecer dos sujeitos que produzem as teorias que performatizam, sempre atentos, aliás, aos efeitos práticos das suas investigações. Eles, os cientistas (neste caso, os profissionais da economia), costumam justamente provar a excelência de uma interpretação através da eficácia com a qual, no plano microeconômico, por exemplo, os preços de uma determinada mercadoria convergem para um novo indicador ou, no plano macroeconômico, por meio da diminuição das taxas de inflação ocasionadas por um novo plano de estabilização. Creio que o caminho para transcender a visão que os próprios profissionais têm sobre o poder dos seus modelos é, como sugeri neste artigo, a análise 
histórica e comparativa da produção das teorias e dos processos de cultivo econômico de populações diversamente relacionadas com os dispositivos implementados pelos especialistas.

O segundo ponto tem a ver com os "efeitos não desejados" da teoria econômica - algo que até agora parece ter merecido pouca atenção por parte dos sociólogos e dos antropólogos da economia, embora costume ser considerado pelos especialistas quando denunciam, por exemplo, as "conseqüências nocivas", ou os "erros", de determinada política ou tecnologia produzida por seus colegas. A visão aqui proposta sobre o papel dos profissionais da economia como verdadeiros pedagogos da instabilidade monetária (produzindo dispositivos e categorias para conceituar o dinheiro e para que os agentes econômicos possam lidar eficazmente com a perda do seu valor) sugere até que ponto os profissionais da economia contribuíram para a construção da doença que eles mesmos, enquanto money doctors, tentaram mais de uma vez remediar. ${ }^{36}$

O último ponto diz respeito à própria noção de "efeito" e à teoria da causalidade subjacente à idéia de performatividade. Um exame mais detalhado das complexas relações entre os dispositivos para "curar" as moedas eliminando a inflação, as disposições e as práticas dos agentes a eles submetidos permite iluminar outra dimensão até agora não considerada no tratamento de tal questão. Na dupla qualidade dos números que medem o valor do dinheiro, como os indicadores de custo de vida e os indexadores, podemos reconhecer um tipo de magia presente em outros dispositivos semelhantes: ao mesmo tempo em que procuram descrever o comportamento empírico de agentes econômicos no passado, reclamam o poder de organizar o comportamento futuro.

Apesar das significativas diferenças que, por exemplo, envolviam a história social do uso generalizado dos indexadores no Brasil e do dólar na Argentina, ambos cumpriam perfeitamente uma das propriedades mais instigantes do dinheiro, e que foi descrita por Simmel (1987 [1909]): a sua "circularidade", o fato de ele ser uma modalidade particular de "representação normativa que se submete às suas próprias normas" (1987:113), um tipo singular de objeto que é, ao mesmo tempo, "efeito de determinadas correntes culturais" e "causa eficiente dessas mesmas correntes" (:181). Exemplos extremos de instrumentos que simultaneamente descrevem e prescrevem, esses números públicos encerram toda a dinâmica das relações entre teorias econômicas e culturas econômicas que a teoria da performatividade deixa de observar, isto em função da noção simplificada de causalidade que ela supõe - sempre de "uma" teoria "sobre" os fatos. Produto da dinâmica de relações de interdependência e de concorrência interna no campo dos pro- 
fissionais, instrumentos como os indicadores, as moedas virtuais, as tabelas de conversão entre moedas e indicadores ou a própria correção monetária procuram interpretar e acompanhar mecanismos culturais preexistentes, ao mesmo tempo em que se transformam, eles mesmos, em dispositivos culturais com efeitos mais amplos e distintos dos originalmente previstos por seus fabricadores - alcançando ainda a própria teoria econômica e os dispositivos criados com base nela.

Assim, compreende-se melhor o objetivo final deste artigo: assinalar a rentabilidade de modelos explicativos mais plásticos, que permitam compreender, de forma nuançada e através de uma perspectiva histórica e comparada, dimensões significativas das relações entre as economias eruditas e as economias ordinárias, perguntando-se sobre as relações dos dois sentidos que a palavra economia possui na linguagem ordinária: um conjunto de teorias sobre a sociedade - um saber especializado - e um conjunto de práticas e idéias - um domínio que ao se apresentar está, ou deveria estar, relativamente separado dos outros.

Recebido em 08 de fevereiro de 2007

Aprovado em 15 de março de 2007

Federico Neiburg é professor do PPGAS (Museu Nacional, UFRJ); pesquisador do CNPq e da FAPERJ; e coordenador do Núcleo de Pesquisas em Cultura e Economia (NuCEC, www.cultura-economia.org).<E-mail: fneiburg@terra.com.br>.

\section{Notas}

* Este artigo baseia-se na conferência pronunciada no Instituto de Ciências Sociais da Universidade de Lisboa, em 7 de abril de 2006. Agradeço especialmente aos meus anfitriões nessa ocasião, João de Pina Cabral e João Vasconcelos, pela sua hospitalidade e pela generosidade dos seus comentários. Agradeço também aos membros do Núcleo de Pesquisas em Cultura e Economia (NuCEC), em cujo seminário foram discutidas versões preliminares, especialmente, Carla Ramos, César Gordon, Diana Lima, Eugênia Motta, Fernando Rabossi, José Renato Baptista, Mariana Cavalcanti, Pedro Braum de Azevedo Silveira e Ricardo Cruz. Por fim, sou grato também a Alexandre Roig e Bruno Théret por suas críticas e sugestões. 
${ }^{1}$ A construção social da confiança pública nos números, na segunda metade do século XIX e nas primeiras décadas do século XX, nos Estados Unidos, associada, por exemplo, à legitimação de algumas profissões como a engenharia ou a contabilidade (e à invenção dos cálculos de custo/ benefício), foi sugestivamente analisada por Porter (1995).

${ }^{2}$ Independente do fato de que as categorias que servem para medir os aumentos de preços são parte do fenômeno que elas descrevem — como pretendo argumentar ao longo deste ensaio - é preciso mencionar alguns números para ilustrar a dimensão do fenômeno: durante quase toda a segunda metade do século XX, no Brasil e na Argentina, houve aumentos anuais de preços superiores a 100\%. Nos anos 80 e 90 , as moedas nacionais de ambos os países desvalorizaram-se por longos períodos a taxas de $1 \%$ ao dia, mais do que $100 \%$ ao mês, chegando a níveis anuais de $1000 \%$. Na Argentina, em 1989, houve um surto de 5000\%; no Brasil, em 1994, de 3000\%. Mais adiante, a singularidade destes processos será melhor observada através de alguns contrastes com outras inflações que mereceram grande atenção na história monetária contemporânea, como a hiperinflação alemã dos anos 20 (que alcançou em 1923 os fantásticos 75 bilhões \%), ou a inflação norte-americana dos anos 70 que, apesar de nunca superar a marca anual (comparativamente modesta) de $17 \%$, transformou-se em assunto público de grande relevância, contribuindo para o renascimento do interesse dos especialistas pelos processos de desvalorização monetária.

${ }^{3}$ Nesse sentido, esta abordagem diferencia-se da interessante proposta de Stephen Gudeman e Alberto Rivera (1990), orientada para observar as possíveis "conversações" entre a economia dos textos e a economia dos camponeses colombianos, junto aos quais eles trabalharam. Ao contrário da intenção de Gudeman e Rivera, de serem eles mesmos os mediadores entre as categorias teóricas dos especialistas e as categorias práticas dos seus interlocutores que, segundo eles esclarecem, não leram as obras dos especialistas, no campo apontado neste artigo abre-se a possibilidade de uma reconstrução empírica fina das relações estabelecidas pelos próprios agentes sociais, mais ou menos "eruditos", mais ou menos "leigos" (no limite, colocando-se em questão a própria distinção entre esses dois universos).

${ }^{4}$ A economia como disciplina universitária autônoma é um fenômeno do século XX. Nas últimas décadas do século XIX, foram fundados os pioneiros cursos e cadeiras de economia. A primeira delas, a cargo de Alfred Marshall, foi estabelecida na universidade de Cambridge em 1890.

${ }^{5}$ Ver, por exemplo, Keynes (1963 [1919-31]).

${ }^{6}$ Em um artigo já clássico, Keith Hart (1986) mostrou que o convívio tenso entre estas duas explicações a respeito da natureza do dinheiro (uma que enfatiza a dimensão quantitativa, e a outra, os aspectos políticos, ligados à confiança no poder soberano que emite, garante e regula o valor da moeda) é um fenômeno mais geral, que pode ser encontrado em outros contextos históricos e culturais, não só entre as teorias nativas do dinheiro moderno, como as teorias econômicas acadêmicas aqui referidas, mas também, por exemplo, nas teorias trobriandesas do valor, descritas por Malinowski, no contraste entre os objetos kula e gimwali. 
${ }^{7}$ A força da utopia monetária da economia ortodoxa, coerente com a utopia do mercado auto-regulado, tão bem descrita por Karl Polanyi (2002 [1944]), tem sido responsável, em boa medida, pela falta de atenção dada pela teoria econômica às desordens monetárias, vistas tão somente como desvios de curto prazo de uma tendência ao equilíbrio que deveria se verificar a longo prazo (ver Ingham 2004:152).

${ }^{8}$ De fato, Simmel (1987 [1909]) procurava um ponto intermediário entre a escola histórica e a neoclássica, aceitando desta última a idéia de que as trocas e, em boa medida, o valor dos objetos resultam do jogo de preferências subjetivas, mediadas pelo símbolo "neutral" do dinheiro.

${ }^{9}$ Neste ponto, Simmel aproxima-se efetivamente da idéia de alienação de Marx. São deste último (Marx 1980 [1844]:177-9) afirmações fulminantes, como "O dinheiro é o objeto por excelência [...] o poder alienado da humanidade". Vale a pena notar, ainda no que diz respeito à sociologia alemã, que embora Max Weber não tenha escrito nenhuma obra específica sobre o dinheiro, nas passagens dedicadas à gênese dos bancos sugere relações entre o uso da moeda como unidade de conta e a gênese social do cálculo e a abstração racional (ver p.e. Weber 1991 [1921]:259-88).

${ }^{10}$ Como mostrou Louis Dumont (1977), essa forma de relacionar (separando) pessoas e coisas constitui um dos pilares da ideologia individualista moderna que se exprime nas teorias econômicas. Pode-se acrescentar que ela é, de fato, um dos pilares das utopias monetárias às quais estou aqui me referindo.

${ }^{11}$ Para um argumento semelhante sobre as dificuldades em tornar essas dimensões do dinheiro objeto de pesquisa antropológica, ver Hart 2004; Zelizer 1994, o número 45 (2005) da revista Terrain, dedicado a "L'argent en famille"; e Baptista (neste mesmo número de Mana). Ver também Maurer (2006) para um panorama da incipiente literatura anglo-saxônica recente que trata do dinheiro em antropologia. Para observar algumas das significativas pontes entre essa problemática associada ao dinheiro e a antropologia da quantificação, ver em especial Weber (2002), e também Zaloom (2003).

${ }^{12}$ Estas considerações explicam também por que, para o argumento deste texto, os termos "moeda" e "dinheiro" podem ser tomados como sinônimos, da mesma forma que eles são utilizados na linguagem ordinária em português ou em espanhol. Nesse sentido, não interessam aqui as distinções estabelecidas por alguns autores que escrevem em língua inglesa sobre money e currency, reservando o primeiro termo às moedas modernas, oficiais, dos estados nacionais, e o segundo, às moedas territoriais, locais (p.e., Akin \& Robbins 1999, ou Helleiner 2003). Para uma reflexão bem informada sobre a gênese e o uso dessa distinção em língua alemã (Geld/Münze), ver o comentário de Alban Bensa (1992) à obra de Bernhard Laum, Heiliges Geld (1924). Ver também Théret no prelo: nota 32.

${ }^{13}$ Ver, por exemplo, Hoppit (2006).

${ }^{14}$ Ver Zelizer (1983). 
${ }^{15}$ Os índices de custo de vida são uns entre os vários index numbers, criados por um tipo de economistas com forte formação matemática e estatística, que têm sido um instrumento central para fundar uma interpretação, segundo esses especialistas, "científica" (porque quantificadora) do comportamento humano e da vida social. Os números relativos às "contas nacionais", como os que medem o PIB ou aqueles que servem para medir pobreza e desigualdade, são também exemplos de index numbers. Embora a história social e cultural desses números esteja ainda por ser feita, é possível ver a respeito, por exemplo, Diewert (2003: cap.1), e Porter (1986:261-269). A prática de elaborar índices nacionais de custo de vida difundiu-se de modo desigual entre os países da Europa Ocidental e da América Latina, mas só se generalizaria bem depois da Segunda Guerra Mundial.

${ }^{16}$ A trajetória de Fisher e suas inovações teóricas e tecnológicas merecem uma investigação à parte. Basta mencionar o fato de que sua "mentalidade sistemática" (como gostam de frisar os biógrafos) produziu também outras invenções com as quais convivemos cotidianamente, como o sistema de cartões para organizar dados, conhecido como "kardex", que sobrevive ainda hoje em muitas bibliotecas. Fisher foi sócio-fundador da Rand-Kardex Co., origem da empresa Remington, fabricante de máquinas de escrever e calculadoras. Sobre Fisher, ver Tobin (2005) e a biografia do seu filho, Fisher (1956). Sobre os títulos indexados, Shiller (2005).

${ }^{17}$ Sobre a generalização do uso de moedas paralelas na Argentina, ver Luzzi (2005). Para uma visão mais ampla sobre o fenômeno, em termos comparativos, ver Blanc (2000).

${ }^{18}$ Inspirado em Reinhard Kosseleck, Claudio Lomnitz (2003) utilizou de forma sugestiva a expressão "saturação de presente" para descrever a percepção temporal das classes médias mexicanas da crise dos anos 1970 e 1980. De acordo com essa perspectiva, há a caracterização de Bernd Widdig (2001) (motivada na análise da crise alemã de 1923, proposta por Canetti [1984]) de que a inflação manifesta, do ponto de vista cultural, uma modernidade "fora de limites" [out of bounds] na inter-relação entre a exacerbação da circulação, a massificação e a depreciação do valor dos objetos (Widdig 2001:23). Raros exemplos de descrições de corte etnográfico dos processos inflacionários argentino e brasileiro estão em Spitta 1988; DaMatta 1993; Sigal \& Kessler 1997; e O'Dougherty 2002. Entre as referências originadas no ensaio ou na literatura (todas relativas ao caso alemão), vale mencionar Thomas Mann 1975 [1942]; Stefan Zweig 1943; e Elias Canetti 1984.

${ }^{19}$ Sobre o contraste com a inflação alemã, deve considerar-se a profundidade temporal, tanto das séries que descrevem a depreciação do valor da moeda, quanto da própria construção da inflação, como assunto público de primeira grandeza. Na Alemanha, as séries que mostram a depreciação do marco começaram na Primeira Guerra, isto é, 15 anos antes da explosão hiperinflacionária de 1923, à qual se seguiu uma imediata estabilização. No Brasil e na Argentina, o período inflacionário e a discussão pública do problema da perda do valor do dinheiro estenderam-se por mais de 50 anos. 
${ }^{20}$ Para uma análise geral sobre as relações entre as teorias econômicas e as culturas da inflação, que considera a dinâmica diferencial do campo dos economistas no Brasil e na Argentina, ver Neiburg (2006a).

${ }^{21}$ A expressão "etnografia autobiográfica" é de Eduardo Archetti (2003:16).

${ }^{22}$ Ver a sugestiva descrição da intensificação, naquela época, do consumo entre as classes médias brasileiras proposta por O'Dougherty (2002).

${ }^{23}$ Ver, por exemplo, Jornal do Brasil, de 01/01/1964, p.1.

${ }^{24}$ Alguns dados gerais sobre a expansão do campo dos economistas no Brasil podem ser vistos em Loureiro (1997), e sobre o jornalismo econômico, em Abreu (2003). As primeiras medições de preços apontando para o cálculo de indicadores de inflação foram realizadas a partir de 1939 pela FIPE (Fundação Instituto de Pesquisas Econômicas) para o município de São Paulo; a partir de 1944, a Fundação Getúlio Vargas começou a produzir o indicador de variação de preços do estado da Guanabara; e em 1955, o recém-criado Departamento Intersindical de Estatística e Estudos Sócio-Econômicos (DIEESE) começou a produzir um outro indicador de custo de vida, referido a trabalhadores sindicalizados do estado de São Paulo. Ainda hoje podem ser encontrados bons exemplos dessa dinâmica de indexação da vida social associada à proliferação de laboratórios de fabricação de números: a Fundação Getúlio Vargas, um dos principais desses laboratórios no Brasil, anunciou recentemente a divulgação pela primeira vez de um "índice de preços para jovens" que poderão, junto com os seus pais, "calcular melhor o valor justo das suas mesadas". Há neste momento também uma equipe da mesma fundação trabalhando na elaboração de um "índice para idosos", que visa subsidiar o debate público a respeito do valor justo das aposentadorias. Enfim, são os números uma afirmação quantitativa do valor do dinheiro, agindo de modo crucial nas relações entre as gerações.

${ }^{25}$ Folha de S. Paulo, de 27/08/1978, p.31. Para uma descrição detalhada dessa polêmica pública a respeito dos números, associada ao processo de proliferação dos indicadores e dos laboratórios de indexação e à expansão do campo dos profissionais da economia, ver Neiburg (no prelo).

${ }^{26}$ Para um exame da dinâmica de produção e legitimação das teorias da inflação inercial, ver Neiburg (2006a:621-25).

${ }^{27}$ Evidentemente, trata-se de condições necessárias, mas não suficientes para dar conta do contraste. Uma descrição da dinâmica dessas diferenças, isto é, uma exploração mais aprofundada da dimensão comparativa na pesquisa da qual este trabalho é um resultado ainda preliminar, exige considerar-se uma pluralidade de elementos que excedem os objetivos deste artigo. Tentativas de construir os parâmetros dessa comparação podem ser vistas em Neiburg (2004 e 2006b).

${ }^{28}$ Algumas figuras, como Julio Nudler e Daniel Muchnik, em entrevistas a F. Neiburg em 2/10/2003 e 30/10/2003, relataram a experiência na produção e na 
distribuição, nos anos 60, dessas folhas com a cotação do dólar como o início do processo da sua conversão em "jornalistas econômicos", o que só aconteceria uma década depois.

${ }^{29}$ A expressão é de Domingo Cavallo, presidente do Banco Central e depois Ministro da Fazenda, em duas ocasiões.

${ }^{30}$ As atas do Fórum sobre dolarização na América Latina, promovido pelo FMI em 1999, ilustram o tom desse debate, no qual os especialistas faziam aparecer de modo crucial as suas interpretações a respeito das culturas monetárias dos seus conacionais (ver IMF, 1999).

${ }^{31}$ A teoria era uma generalização do slogan utilizado na época pela campanha publicitária da conhecida vodka Orloff, em que um personagem, referindo-se aos efeitos colaterais positivos (contra a ressaca) da bebida, advertia (antes de tomar): "Eu sou você amanhã". O uso de bebidas alcoólicas para falar do contágio da doença monetária se generalizaria pouco depois, com os efeitos "tequila", "vodka", "caipirinha" etc.

${ }^{32}$ A utilização da imagem da doença visando lidar com o valor da moeda tem uma longa história. Ela recua até os inícios da reflexão propriamente moderna sobre o dinheiro, no contexto do processo de homogeneização e centralização monetárias iniciado no século $\mathrm{XV}$, quando se estabeleceu também, por exemplo, a distinção ainda hoje vigente entre os economistas, de moedas autênticas e moedas espúrias ou quase-moedas (ver, p.e., Kaye 1988). A atualidade da relação entre doença e instabilidade monetária pode ser verificada observando-se os objetivos dos modernos Bancos Centrais: o primeiro deles sempre é "cuidar da saúde da moeda".

${ }^{33}$ Ver Neiburg (2005). Ver também Dixon (1998:47-60) e Lebaron (2000:176-81), respectivamente, para Grã-Bretanha e França. Sobre o uso de metáforas naturais na legitimação pública da ciência econômica, ver Mirowski (1994).

${ }^{34}$ Callon baseia a sua demonstração em um extenso comentário do trabalho de Marie-France Garcia (1986), em que ela reconstrói empiricamente, em um caso concreto, o processo através do qual se realiza o ideal do mercado perfeito.

${ }^{35}$ Sobre esse debate, ver também Callon (2005) e Aspers (2005).

${ }^{36}$ A expressão money doctor generalizou-se na América Latina já no fim do século XIX (Drake 1994). 


\section{Referências bibliográficas}

ABREU, Alzira A. 2003. "Jornalistas e jornalismo econômico na transição democrática". In: A. Abreu, F. Lattman-Weltman \& M. Almeida Kornis (orgs.), Mídia e política no Brasil: jornalismo e ficção. Rio de Janeiro: Editora FGV. pp. 13-74.

AGLIETTA, Michel \& ORLÉAN, André (orgs.). 2002. La monnaie entre violence et confiance. Paris: Odile Jacob.

AKIN, David \& ROBBINS, Joel. 1999. "An introduction to melanesian currencies. Agency, identity, and social reproduction". In: D. Akin \& J. Robbins (orgs.), Money and modernity. State, and local currencies in Melanesia. Pittsburgh: University of Pittsburgh Press. pp. 1-40.

ARCHETTI, Eduardo. 2003. Masculinidades. Fútbol, tango y polo en la Argentina. Buenos Aires: Antropofagia.

ASPERS, Patrik. 2005. "Performativity, neoclassical theory and economic sociology". Economic Sociology. European Electronic Newsletter, 6(2): 33-39.

AUSTIN, John L. 1972. How to do things with words. Oxford: Oxford University Press.

BAPTISTA, José Renato de Carvalho. 2007. "Os deuses vendem quando dão: os sentidos do dinheiro nas relações de troca no Candomblé". Mana. Estudos de Antropologia Social, 13(1):7-40.

BENSA, Alban. 1992. "Présentation a 'Genèse et nature de la monnaie' de Bernhard Laum" (capítulo 5 de Argent sacré. Analyse historique de l'origine sacrée de l'argent). Genèses. Sciences Sociales et Histoire, 8:60-64.
BLANC, Jérôme. 2000. Les monnaies parallèles. Unité et diversité du fait monétaire. Paris: L'Harmattan.

BLOCH, Maurice \& PARRY, Jonathan. 1989. "Introduction: money and the morality of exchange". In: M. Bloch \& J. Parry, Money and the morality of exchange. Cambridge: Cambridge University Press. pp. 1-32.

BOHANNAN, Paul. 1967. "The impact of money on an african subsistence economy". In: G. Dalton (org.), Tribal and peasant economies. Readings in economic anthropology. New York: The Natural History Press. pp. 123-35.

BOURDIEU, Pierre. 1981. "Décrire et prescrire. Note sur les conditions de possibilité et les limites de l'efficacité politique". Actes de la Recherche en Sciences Sociales, 38:69-73.

BRESCIANI-TURRONI, Constantino. 1937. The economics of inflation: a study of currency depreciation in Post-War Germany, 1914-23. London: G. Allen and Unwin.

CALLON, Michel. 1998. "Introduction: the embeddedness of economic markets in economics". In: M. Callon (org.), The laws of the markets. Oxford: Malden, MA: Blackwell Publishers. pp.1-57.

2005. "Why virtualism paves the way to political impotence. Callon Replies to Miller". Economic Sociology. European Electronic Newsletter, 6(2):3-21.

CALLON, Michel \& LATOUR, Bruno. 2001. "'Tu ne calculeras pas!' ou comment symétriser le don et le capital". In: A. Caillé (org.), Le capitalisme aujourd'hui. Paris: La Découverte (MAUSS n 9). pp. 45-70. 
CANETTI, Elias. 1984. Crowds and power. New York: Farrar Straus Giroux.

CARRUTHERS, Bruce G. \& BABB, Sarah. 1996. "The color of money and the nature of value: greenbacks and gold in postbellum America". American Journal of Sociology, 101(6):1556-91.

CRUMP, Thomas. 1978. "Money and number: the trojan horse of language". Man, New Series, 13(4):503-18.

DALTON, George. 1967. "Primitive money." In: G. Dalton (org.), Tribal and peasant economies. Readings in economic anthropology. New York: The Natural History Press. pp.254-81.

DAMATTA, Roberto. 1993. "Para uma sociologia da inflação: Notas sobre inflação, sociedade e cidadania." In: J. Ribas Vieira et alii (orgs). Na corda bamba: doze estudos sobre a cultura da inflação. Rio de Janeiro: Relume Dumará. pp.15-31.

DIEWERT, W. Erwin. 2003. Index number theory and measurement economics. Greenwich: JAI Press.

DIXON, Keith. 1998. Les évangélistes du marché. Paris: Raison d'Agir.

DOUGLAS, Mary. 1986. How institutions think. Syracuse: Syracuse University Press.

DRAKE, Paul W. 1994. Money doctors, foreign debts, and economic reforms in Latin America from the 1890s to the present. Wilmington: SR Books.

DUMONT, Louis. 1977. Homo aequalis. Paris: Gallimard.

ELIAS, Norbert. 2006 [1984]. "Sobre a sociogênese da economia e da sociologia". In: F. Neiburg \& L. Waizbort (orgs.), Norbert Elias. Escritos \& ensaios, 1. Estado, processo, opinião pública. Rio de Janeiro: Jorge Zahar. pp.167-196. 2000 [1976]. "Nota sobre os conceitos de 'estrutura social' e 'ano- mia'". In: Os estabelecidos e os outsiders. Uma sociologia do poder a partir de uma pequena comunidade. Rio de Janeiro: Jorge Zahar. pp. 190-3.

FELDMAN, Gerald. D. 1993. The great disorder: Politics, economics, and society in the german inflation, 19141924. New York: Oxford University Press.

FISHER, Irving. 1911. The purchasing power of money. New York: Macmillan.

. 1921. "Dollar stabilization". In: Enciclopédia Britânica, XXX, pp. 852-853.

. 1922. The making of index numbers. Boston: Houghton Mifflin.

FISHER, Irving. N. 1956. My father Irving Fisher. New York: Comet Press.

FOUCAULT, Michel. 1994. "Naissance de la biopolitique". In: Dits et écrits, v.III. Paris: Gallimard. pp. 819-25.

GARCIA, Marie-France. 1986. "La construction sociale d'une marché parfait: le marché au cadran de Fontainesen-Sologne." Actes de la Recherche en Sciences Sociales, 65:2-13. 1996. "Represéntations savantes et pratiques marchandes". Gènese. Sciences Sociales et Histoire, 25:50-71.

GILBERT, Emily. 2005. "Common cents: situating money in time and place". Economy and Society, 34(3):357-388.

GUDEMAN, Stephen \& RIVERA, Alberto. 1990. Conversations in Colombia. The domestic economy in life and text. Cambridge: Cambridge University Press.

GUDIN, Eugênio. 1967. "A institucionalização da inflação". Digesto Econômico, 163.

GREGORY, Chris A. 1997. Savage money. The anthropology and politics of commodity exchange. Amsterdam: Harwood Academic. 
HART, Keith. 1986. "Heads or tails? Two sides of the coin". Man, 21:637-56. 2004. "Money: one anthropologist's view". In: J. Carrier (org.), Handbook of economic anthropology. Northampton: Edward Elgar. pp. 160-175.

HELLEINER, Eric. 2003. The making of national money: territorial currencies in historical perspective. Ithaca: Cornell University Press.

HIRSCHMAN, Albert. 1984 [1981]. "La matriz social y política de la inflación: elaboración sobre la experiencia latinoamericana." In: A. Hirschman (org.), De la economía a la política y más allá. México: Fondo de Cultura Económica. pp. 225-267.

HOPPIT, Julian. 2006. "Political arithmetic in eighteenth-century England". The Economic History Review, New Series, 49(3):516-540.

INGHAM, Geoffrey. 2004. The nature of money. Cambridge: Polity Press.

KAYE, Joel. 1988. "The impact of money on the development of fourteenthcentury scientific thought". Journal of Medieval Studies, 14:251-70.

KEYNES, John Maynard. 1963 [191931]. "Inflation". In: Essays in persuasion. New York: Norton \& Norton. pp. 77-104.

KOSELECK, Reinhard. 1999. Crítica e crise. Rio de Janeiro: Contraponto.

LAVE, Jane. 1988. Cognition in practice. Mind, mathematics and culture in everyday life. Cambridge: Cambridge University Press.

LEBARON, Frédéric. 2000. La croyence économique. Les économistes entre science et politique. Paris: Seuil.

L'HOMME. 2002. "Questions de monnaie" ${ }^{\prime \prime} \mathrm{n}^{\circ}$ 162. Paris: EHESS.

LIESNES, T. \& KING, M. 1975. Indexing for inflation. Londres: Educational Book.

LOMNITZ, Claudio. 2003. "Times of crisis: historicity, sacrifice, and the spectacle of debacle in Mexico City". Public Culture, 15(1):127-47.

LOUREIRO, Maria Rita. 1997. Os economistas no governo. Rio de Janeiro: Fundação Getulio Vargas.

LUZZI, Monica. 2005. Réinventer le marché? Les clubs de troc face à la crise en Argentine. Paris: Editions L'Harmattan.

MACKENZIE, Donald \& MILLO, Yuval. 2003. "Negotianting a market, performing theory: the historical sociology of a financial derivatives exchange". American Journal of Sociology, 109(1): 107-46

MANN, Thomas. 1975 [1942]. "Inflation: the witches sabbath: Germany 1923". Encounter, 44(2):60-64.

MARX, Karl. 1980 [1844]. Manuscritos de economía y filosofía. Madrid: Alianza Editorial.

MAURER, Bill. 2006. "The anthropology of money". Annual Review of Anthropology, 35:295-315.

MAUSS, Marcel. 1974 [1934]. “Débat sur les fonctions sociales de la monnaie". In: Oeuvres 2. Représentations collectives et diversité des civilisations. Paris: Minuit. pp.116-120.

MILLER, Daniel. 2002. "Turning Callon the right way up". Economy and Society, 31(2):218-32.

MIROWSKI, Philip (org.). 1994. Natural images in economic thought. Cambridge: Cambridge University Press.

MOURA DE MELO, Francisco de Assis. 1986. "IGP ou IPCA: como estimadores da inflação e indexadores da economia brasileira". Revista de Economia e Política, 6(2):100-108.

NEIBURG, Federico. 2004. "Economistas y elites estatales en Brasil y Argentina, 1980-2000. Esbozo de una sociología comparada de la cultura a propósito del efecto Orloff". Prismas. Revista de Historia de la Cultura, 8:205-214. 
2005. "Inflación y crisis nacional. Culturas económicas y espacios públicos en la Argentina y Brasil". Anuario de Estudios Americanos, 62(1):113-138.

. 2006a. "Inflation: economists and economic cultures in Brazil and Argentina". Comparative Studies in Society and History, 48(3):604-633. 2006b. "Moedas doentes e culturas econômicas. Em favor de um comparatismo multicentrado". Paper apresentado na Mesa Redonda "Comparações: dos nativos e dos antropólogos", 25a Reunião da Associação Brasileira de Antropologia, Goiânia, 11-14 de junho.

. (no prelo). "A proliferação dos números públicos e a indexação da vida social". In: F. Neiburg (org.), Quantificação e temporalidade. Perspectivas etnográficas sobre a economia. Rio de Janeiro: Garamond. cap. 6.

O'DOUGHERTY, Maureen. 2002. Consumption intensified. The politics of middle-class daily life in Brazil. Durham: Duke University Press.

ORLÉAN, André. 2002. "La monnaie, opérateur de totalisation". Journal des Anthropologues, 90-91:331-352. . (no prelo). "L'hyperinflation allemande des années 1920". In: B. Théret (org.), La monnaie dévoilée par ses crises. Paris: Ed. MSH. cap. 21.

POLANYI, Karl. 1957. "The economy as instituted process". In: C. Polanyi, Arensberg \& Pearson (orgs.). Trade and markets in the early empires. Economies in history and theory. New York: Free Press. pp. 64-95. . 2002 [1944]. The great transformation. The political and economic origins of our time. New York: Beacon Press.

PORTER, Theodore M. 1986. The rise of statistical thinking, 1820-1900. Princeton: Princeton University Press.
1995. Trust in numbers. The search for objectivity in science and public life. Princeton: Princeton University Press.

RICHARD, Lionel. 1983. La vie quotidienne sous la République de Weimar. Paris: Hachette.

SARGENT, Thomas. 1999. The conquest of american inflation. Princeton: Princeton University Press.

SCHUMPETER, Joseph A. 1996 [1954]. A history of economic analysis. London: Routledge.

SHILLER, Robert J. 2005. "The invention of inflation-indexed bonds in Early America". In: W. Goetzmann \& G. Rouwenhorst (orgs.), The origins of value: the financial innovations that created modern capital markets. Oxford: Oxford University Press.

SIGAL, Silvia. \& Kessler, Gabriel. 1997. "La hiperinflación en Argentina: comportamientos y representaciones sociales". In: D. Canton \& J. R. Jorrat (orgs.), La investigación social hoy. Buenos Aires: CBC/UBA. pp. 155-187.

SIMIAND, François. 1934. "La monnaie, réalite sociale". Année Sociologique (série D), 1:1-58.

SIMMEL, Georg. 1987 [1909]. La philosophie de l'argent. Paris: PUF.

SPITTA, Arnold. 1988. "La cultura de la inflación en la Argentina. Observaciones cotidianas de un extranjero". In: N. Botana \& P. Waldmann (orgs.), El impacto de la inflación en la sociedad y la política. Buenos Aires: Tesis/ ITDT. pp. 125-150.

STEINER, Philippe. 2005. L'école durkheimienne et l'économie. Sociologie, religion et connaissance. Genève: Droz.

TERRAIN. 2005. "L'argent en famille", n. 45.

THÉRET, Bruno (no prelo). "La monnaie $\mathrm{au}$ prisme de ses crises d'hier et 
d'aujourd'hui. Introduction générale". In: B. Théret. (org.), La monnaie dévoilée par ses crises. Paris: Ed. MSH.

TOBIN, James. 2005. "Irving Fisher (1867-1947)". The American Journal of Economics and Sociology, 64(1): $19-42$

IMF Economic Forum. 1999. "Dollarization: fad or future for Latin America". Washington, June 24-26.

WEBER, Florence. 2002. "Práticas econômicas e formas ordinárias de cálculo". Mana. Estudos de Antropologia Social, 8(2):151-182.

WEBER, Max. 1991 [1921]. Histoire économique. Esquisse d'une histoire universelle de l'économie et de la société. Paris: Gallimard.

WIDDIG, Bernd. 2001. Culture and inflation in Weimar Germany. Berkeley:
University of California Press.

ZALOOM, Caitlin. 2003. "Ambiguous numbers: trading technologies and interpretation in financial markets". American Ethnologist, 30(2): 258-72.

ZELIZER, Viviana. 1983. Morals and markets. The development of life insurance in the United States. New Jersey: Transaction Books.

1994. The social meaning of money. Pin money, paychecks, poor relief and other currencies. New York: Basic Books. 2003 "Sociology of money". In: Neil J. Smelser \& Paul B. Baltes (orgs.), International Encyclopedia of the Social \& Behavioral Sciences, 15:9991-4. Amsterdam: Elsevier.

ZWEIG, Stefan. 1943. The world of yesterday, an autobiography. New York: Viking Press. 
Resumo

Situado na fronteira entre a antropologia da ciência (econômica) e a antropologia das culturas monetárias, este artigo propõe uma compreensão dos sentidos sociais e culturais do dinheiro centrada na análise das articulações entre as idéias e as práticas monetárias eruditas e as ordinárias. O texto critica a matriz analítica normativa que predomina em boa parte da literatura sociológica, tributária da própria ciência econômica, e que está preocupada em diagnosticar a "natureza" dos "problemas monetários", distinguindo moedas "normais" de "doentes". Critica também a matriz que predomina em boa parte da literatura antropológica que observa a moeda através da lente da grande divisão entre as moedas "modernas" e as "outras". Ao ter como principal referência empírica as inflações brasileira e argentina da segunda metade do século $\mathrm{XX}$, sugere uma agenda de pesquisas que considera: 1. a presença dos modelos e dos dispositivos monetários criados pelos especialistas nos sentidos e nas práticas ordinárias associadas com o dinheiro; 2 . a presença das idéias e das práticas monetárias ordinárias nas formas através das quais os especialistas percebem e agem sobre a moeda; 3. o fato de que os universos de produção de idéias e de dispositivos monetários eruditos, isto é, aqueles que estão referidos às teorias e às políticas monetárias, são suscetíveis de serem analisados com os mesmos instrumentos utilizados para estudar qualquer outro universo nativo; e 4. que esse universo de idéias e de práticas, como não poderia ser de outro modo, está situado no tempo e exige uma análise histórica.

Palavras-chave: Dinheiro, Inflação, Culturas Monetárias, Números

\section{Abstract}

Situated on the border between the anthropology of science (economics) and the anthropology of monetary cultures, this article investigates the social and cultural meanings of money through an analysis of the inter-connections between academic and everyday monetary ideas and practices. The text critiques the normative analytic matrix predominant in much of the sociological literature, a product of economic science itself, concerned with diagnosing the 'nature' of 'monetary problems' and distinguishing 'normal' currencies from 'sick' ones. It also critiques the matrix predominant in much of the anthropological literature, which observes currencies through the lens of the great divide between 'modern' currencies and all the 'others.' Focusing primarily on the empirical cases of Brazilian and Argentinean inflation in the second half of the 20th century, it suggests a research agenda that takes into consideration: 1 . the presence of monetary models and instruments created by specialists in the everyday meanings and practices associated with money; 2 . the presence of everyday monetary ideas and practices in the forms through which specialists perceive and intervene in currencies; 3 . the fact that the universes in which these academic ideas and monetary instruments are produced that is, the universes relating to monetary theories and policies - can be analyzed with the same tools used to study any other native universe; and 4. that this universe of ideas and practices is, of course, situated in time and demands an historical analysis.

Key words: Money, Inflation, Monetary Cultures, Numbers 